\title{
Ocurrence of pepper yellow mosaic virus and cucumber mosaic virus on Capsicum chinense in the state of Amazonas, Brazil
}

\author{
Leonor Cristina Silva SOUZA ${ }^{1}$, Rogerio Eiji HANADA ${ }^{1 *} \mathbb{D}$, Luiz Alberto Guimarães ASSIS ${ }^{2}$, \\ Viviana M. CAMELO-GARCÍA', Jorge Alberto Marques REZENDE³, Valdir A. YUKI ${ }^{4}$, Elliot W. KITAJIMA ${ }^{3}$ \\ Instituto Nacional de Pesquisas da Amazônia, Coordenação de Tecnologia e Inovação (COTEI), Av. André Araújo 2936, 69067-375, Manaus, AM, Brazil \\ 2 Instituto Nacional de Pesquisas da Amazônia, Coordenação de Sociedade, Ambiente e Saúde (COSAS), Av. André Araújo 2936, 69067-375, Manaus, AM, Brazil \\ Universidade de São Paulo, Escola Superior de Agricultura Luiz de Queiroz, Departamento de Fitopatologia e Nematologia, Av. Pádua Dias 11, 13418-900, Piraci- \\ caba, SP, Brazil \\ ${ }^{4}$ Instituto Agronômico de Campinas, Centro de Fitossanidade, Av. Barão de Itapura 1481, 13020-902, Campinas, SP, Brazil \\ * Corresponding author: rhanada@inpa.gov.br; (D) https://orcid.org/0000-0002-4544-4882 \\ (iD) https://orcid.org/0000-0001-8688-4852
}

\begin{abstract}
The habanero chilli pepper, Capsicum chinense is an important crop in the Amazon Basin, mainly grown by small-scale producers. Capsicum chinense plants in an experimental field in the northern Brazilian state of Amazonas were found exhibiting characteristic symptoms of viral infection. Leaf sap from symptomatic plants examined under a transmission electron microscope revealed the presence of elongated flexuous particles and isometric particles. Using molecular assays, the viruses were identified as pepper yellow mosaic virus (PepYMV) and cucumber mosaic virus (CMV). Aphids, identified as Aphis gossypii, were found colonizing the $C$. chinense plants in the field and may be the vector for both PepYMV and CMV. We report the first occurrence of these viruses infecting C. chinense in the state of Amazonas.
\end{abstract}

KEYWORDS: Cucumovirus, Potyvirus, transmission electron microscopy, RT-PCR, Aphis gossypii

\section{Ocorrência do pepper yellow mosaic virus e cucumber mosaic virus em Capsicum chinense no estado do Amazonas, Brasil}

\section{RESUMO}

A pimenta-de-cheiro, Capsicum chinense é uma cultura importante na Bacia Amazônica, cultivada principalmente por pequenos produtores. Plantas de $C$. chinense em um campo experimental localizado no norte do estado brasileiro do Amazonas, foram encontradas apresentando sintomas característicos de infecção viral. Extratos de amostras de folhas sintomáticas examinados ao microscópio eletrônico de transmissão revelaram a presença de partículas alongadas e flexuosas e de partículas isométricas. Análises moleculares permitiram identificar a presença do pepper yellow mosaic virus (PepYMV) e do cucumber mosaic virus (CMV). Pulgóes, identificados como Aphis gossypii foram encontrados colonizando pimenteiras-de-cheiro neste campo experimental e podem representar o provável vetor de PepYMV e CMV. Este trabalho relata a primeira ocorrência desses vírus infectando $C$. chinense no estado do Amazonas.

PalaVRas-Chave: Cucumovirus, Potyvirus, microscopia eletrônica de transmissão, RT-PCR, Aphis gossypii

Capsicum chinense Jacq. (Solanaceae), known in northern Brazil as pimenta-de-cheiro, is a genuinely Brazilian chili pepper, because its greatest genetic diversity is found in the Amazon Basin (Carvalho et al. 2006; Moreira et al. 2006). In the state of Amazonas, C. chinense is cultivated mostly by small-scale producers, and in recent years the area planted has increased (IDAM 2016).
Plants of $C$. chinense showing foliar symptoms of mosaic, malformation and blistering, accompanied by stunting (Figure 1 ), suggesting possible viral infection, were observed in an experimental field at Estação Experimental de Hortaliças Dr. Alejo Von der Pahlen (0259'45.7”S, 6001'22.3”W), of Instituto Nacional de Pesquisas da Amazônia (INPA), in Manaus, Amazonas state, Brazil. Symptomatic leaf samples were collected for further analysis. 
Negatively stained leaf extracts from symptomatic samples of $C$. chinense, examined under a JEOL JEM 1011 transmission electron microscope (TEM) revealed the presence of elongated flexuous particles of approximately $13 \mathrm{~nm}$ in width and 700-800 $\mathrm{nm}$ in length, suggesting infection by potyviruses. Many isometric particles $25-30 \mathrm{~nm}$ in diameter, resembling cucumoviruses, were also observed (Figure 2a). For cytopathological studies, infected leaf tissues were

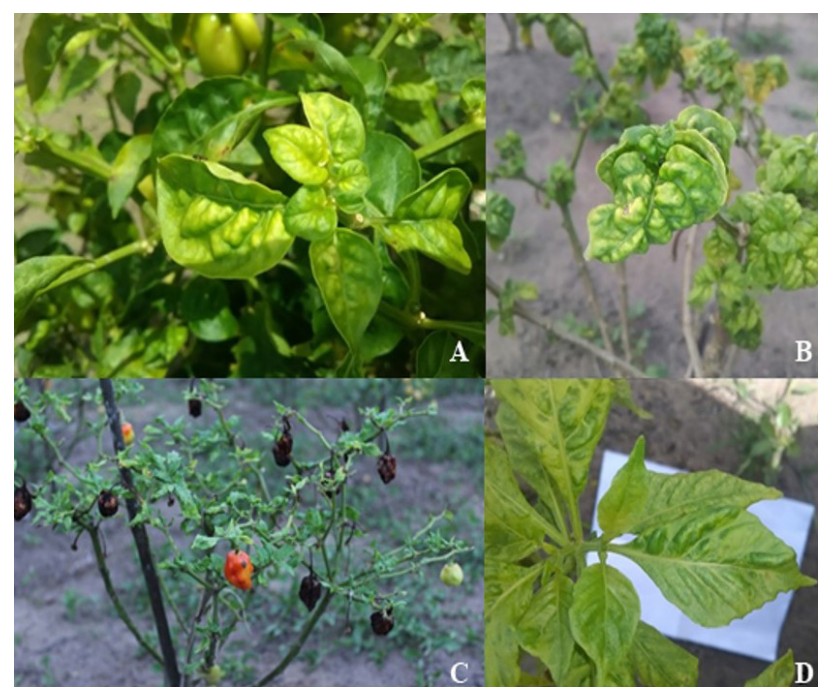

Figure 1. Symptoms exhibited by Capsicum chinense plants in an experimental field in Manaus, Amazonas state, Brazil. (A-B) mosaic and blistering; (C) stunting; (D) mosaic. This figure is in color in the electronic version.
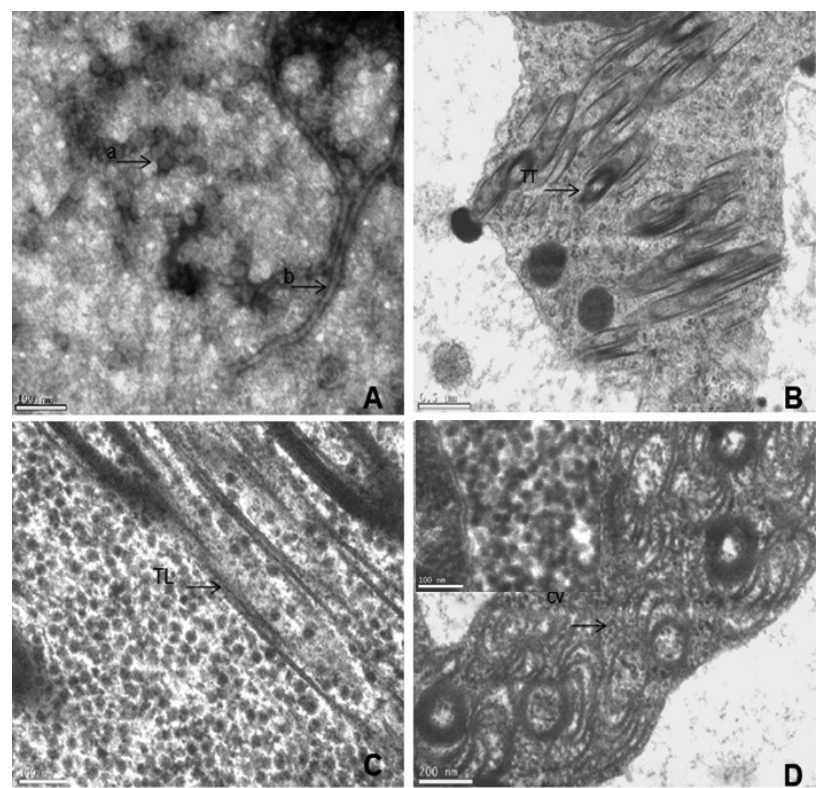

Figure 2. (A) Negatively stained leaf extract exhibing the presence of isometric particles (arrow a), and elongated flexuous virus-like particles (arrow b). (B-D) Transmission electron micrographs of symptomatic Capsicum chinense leaves showing lamellar inclusions forming cylindrical scrolls characteristic of potyvirus infection. TL - cylindrical scrolls cut longitudinally; TT - cross section of cylindrical scroll which, in favorable sections, show pinwheel-like configuration (CV). processed following Kitajima and Nome (1999). Observation of ultrathin sections in the TEM indicated the presence of cytoplasmic lamellar inclusions forming long scrolls (Figure 2b-d), which, in cross section, formed a typical configuration referred to as a pinwheel, characteristic of potyvirus infection (Edwardson 1974). Isometric particles were occasionally seen forming small aggregates in the cytoplasm, which can be distinguished from ribosomal particles due to their smooth profile and slightly larger diameter.

Total RNA was extracted from eight symptomatic $C$. chinense plants using a PureLink Viral RNA/DNA kit (Thermo Fisher Scientific, Waltham, USA) following the manufacturer's recommendations. One-step RT-PCR was performed using universal primers PV1/SP6 and WCIEN-sense, for detection of potyviruses (Mackenzie et al. 1998; Maciel et al. 2011), and specific primers for the coat protein gene of cucumber mosaic virus (CMV) (Wylie et al. 1993), which amplify fragments of 800 and $480 \mathrm{bp}$, respectively. Amplicons of the expected size for each virus were purified and directly sequenced in both directions at Macrogen Inc. (Seoul, South Korea). The consensus nucleotide sequences were obtained using Electropherogram quality analysis (http://bioinformatica. cenargen.embrapa.br/phph/). The identity of the nucleotide sequences was defined using BLASTn (Altschul et al. 1990; Camacho et al. 2009). Nucleotide sequences (GenBank accession numbers MK512671, MK512672 and MK512673) obtained using the universal primers for potyviruses showed $96 \%$ to $98 \%$ identity with corresponding nucleotide sequences from pepper yellow mosaic virus (PepYMV) isolates from Brazil deposited in GenBank (AB541985, AF348610). Likewise, nucleotide sequences of two CMV amplicons (MK512669 and MK512670) showed 97\% to 99\% identity with corresponding nucleotide sequences of different CMV isolates (KX014666, KM091956, KM272276).

Immature and adult aphids were collected from some symptomatic plants and stored in tubes containing 70\% alcohol for further identification. Aphid samples were mounted on slides, and examined under a light microscope for species identification. Aphis gossypii Glover, 1877 (Auchenorrynca: Aphididae) was the only species found in the collected samples, and possibly represents the vector for PepYMV and CMV, both of which are stylet borne (non-persistant) (Whitfield et al. 2015). Identification of Aphis gossipyii followed Blackman and Eastop (1984), using characteristics such as dark siphunculi uniformly sclerotized from tip to base, longer than the tail, and uniformly sclerotized whitish dorsal abdominal segments.

\section{ACKNOWLEDGMENTS}

LCSS received a master's scholarship from Conselho Nacional de Desenvolvimento Científico e Tecnológico (CNPq). Transmission electron microscopy, molecular assays and aphid 
identification procedures were supported by Biota Program from Fundação de Amparo à Pesquisa do Estado de São Paulo (FAPESP 2017/18910-4). The authors are grateful to Dr. Charles Clement of Instituto Nacional de Pesquisas da Amazonia, for editing the English.

\section{REFERENCES}

Altschul, S.F.; Gish, W.; Miller, W.; Myers, E.W.; Lipman, D.J. 1990. Basic local alignment search tool. Journal of Molecular Biology, 215: 403-410.

Blackman, R.L.; Eastop, V.F. 1984. Aphids on the World's Crops. An Identification and Information Guide. John Wiley, Chichester, 466p.

Camacho, C.; Coulouris, G.; Avagyan, V.; Ma, N.; Papadopoulos, J.; Bealer, K.; et al. 2009. BLAST+: Architecture and applications. BMC Bioinformatics, 10: 421.

Carvalho, S.I.C. de; Bianchetti, L. de B.; Ribeiro, C.S. da C.; Lopes, C.A. 2006. Pimentas do gênero Capsicum no Brasil. Embrapa Hortaliças Documentos, 94: 1-27.

Edwardson, J.R. 1974. Some properties of the Potato virus Y group. Florida Agricultural Experiment Stations Monograph Series. Inst. Food Agric. Sci., Univ. Florida, Gainesville, USA, 398p.

IDAM. 2016. Produção de pimentão e pimenta-de-cheiro cresce em mais de $83 \%$ no municipio de Presidente Figueiredo. Instituto de Desenvolvimento Agropecuário e Florestal Sustentável do Amazonas. (http://www.idam.am.gov.br/producao-depimentao-e-pimenta-de-cheiro-cresce-em-mais-de-83-nomunicipio-de-presidente-figueiredo/). Accessed on 06 Sep. 2019.
Kitajima, E.W.; Nome, C.F. 1999. Microscopia eletrónica en virologia vegetal. In: Do Campo, D.; Lenardon, S. (Ed.). Métodos Para Detectar Patógenos Sistémicos, IFFIVE/INTA, Córdoba, p.59-87.

Maciel, S.C.; da Silva, R.F.; Reis, M.S.; Jadão, A.S.; Rosa, D.D.; Giampan, J.S.; et al. 2011. Characterization of a new potyvirus causing mosaic and flower variegation in Catharanthus roseus in Brazil. Scientia Agricola, 68: 687-690.

Mackenzie, A.M.; Nolan, M.; Wei, K.J.; Clements, M.A.; Gowanlock, D.; Wallace, B.J.; et al. 1998. Ceratobium mosaic potyvirus: Another virus from orchids. Archives of Virology, 143: 903-914.

Moreira, G.R.; Caliman, F.R.B.; Silva, D.J.H.; Ribeiro, C.S. da C. 2006. Espécies e variedades de pimentas. Informe Agropecuário, EPAMIG, 27: 16-29.

Whitfield, A.E.; Falk, B.W.; Rotenberg, D. 2015. Insect vector-mediated transmission of plant viruses. Virology, 479-480: 278-289.

Wylie, S.; Wilson, C.R.; Jones, R.A.C.; Jones, M.G.K. 1993. A polymerase chain reaction assay for cucumber mosaic virus in lupin seeds. Australian Journal of Agricultural Research, 44: 41-51.

RECEIVED: 06/10/2019

ACCEPTED: $17 / 11 / 2019$

ASSOCIATE EDITOR: Alexandre Pio Viana 